\title{
手賀沼におけるオオバンの繁殖生態
}

\author{
北 島 信 秋*
}

\section{Breeding Biology of the Coot Fulica atra on Lake Teganuma, Chiba}

\author{
Nobuaki Kitajima*
}

\begin{abstract}
The breeding ecology of the Coot Fulica atra was studied on Lake Teganuma, Chiba, central Japan, from April to October 1990. Nests were built in 2-7 days, and used for copulation and egg laying. The egg laying period ranged from early April to mid-July, peaking in May. One egg was laid per day and clutch size varied from 3-8 eggs, with an average of 5.2. Eggs weighed between 30 and $40 \mathrm{~g}$, averaging $34.9 \mathrm{~g}$. The mean size of 120 eggs from 23 nests was $52.0 \times 35.5 \mathrm{~mm}$. Most nests $(86 \%)$ were placed in Typha angustata, and the other nests (14\%) in Zizania latifolia. Both males and females incubated eggs. The interval of incubation was 51 minutes on average. The incubation period ranged between 21 and 25 days. The second nest was constructed once the eggs had hatched. Of a total of 126 eggs laid in this study area, $32 \%$ hatched, with only $12 \%$ of the eggs remaining after two weeks.
\end{abstract}

Key words: Coot, Fulica atra, breeding ecology, egg laying period, clutch size, incubation period, breeding success.

\section{はじめに}

オオバン Fulica atra は, イギリスからエジプト，ユーラシア大陸，オーストラリア大陸まで 広い地域にわたって分布する (Witherby 1947)。我国でも，北海道之本州の中央部を除いた九州 から四国, 北海道南部までの地域で広く生息・繁殖していることが観察されている（清棲 1965, Brazil 1991 他)。

オオバン類の研究は, 国外では古くから盛んであり, Gullion $(1951,1953,1954)$ や Sooter (1942) がアメリカオオバン Fulica americana の繁殖生態やテリトリー, 換羽, 額板, 雌雄の鳴 き声の違いなどについて, Cramp (1947) や Alley \& Boyd $(1947,1948,1950)$ が, カリフォルニ アでオオバンのテリトリーや艀化，巣立ち状況などについて研究している。我国では，オオバ ンの繁殖地域 (Takatsukasa 1967) や, 食物と採食行動（原田 1988）について報告されているが, 巣作りから育雅までの繁殖生態や非繁殖期の生活についての研究報告はまだない。

筆者が調查した手賀沼（海抜 $5 \mathrm{~m}$ ，東経 $140^{\circ}$ 北緯 $35^{\circ}$ ）は，近年水質污濁（千葉県水質保全 研究所 1981）が顕著であるが, かつてオオバンの有数の渡来地であった（齋藤 1931，千葉県環 境部 1976, 黒田 1985)。昭和 40 年代半ば個体群の崩壊を起こして以後個体数は回復していない

Received 27 March 1991, Revised 6 October 1991, 2nd Revision 1 September 1992, 3rd Revision 2 August 1993, 4th Revision 15 February 1994, Accepted 21 February 1994

* Nabeyata Primary School of Nagano City

Present Address: Wakatsuki Primary School, 810 Wakatsuki Higasijo, Nagano City, 381 Japan. 


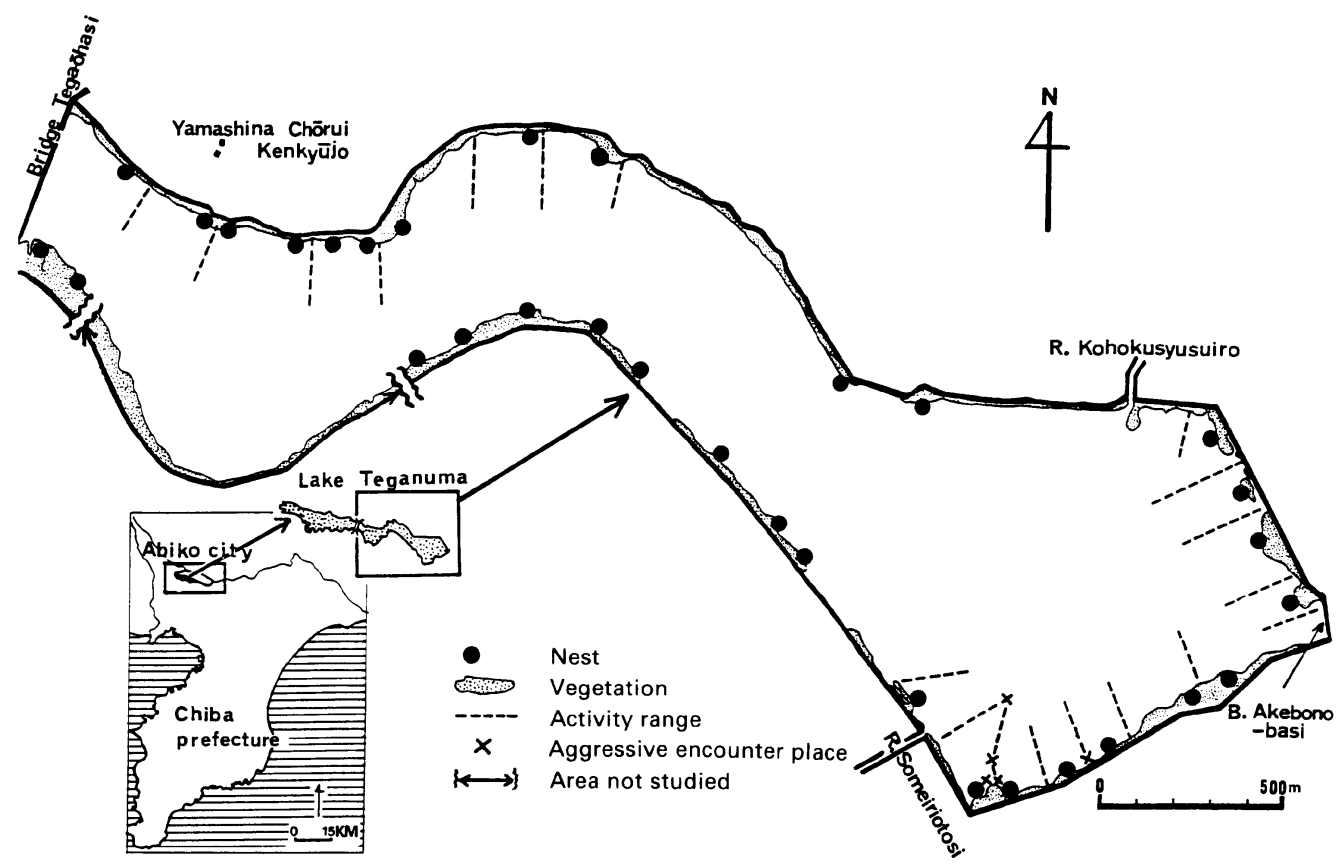

Fig. 1. Map of study area, showing the distribution of nests.
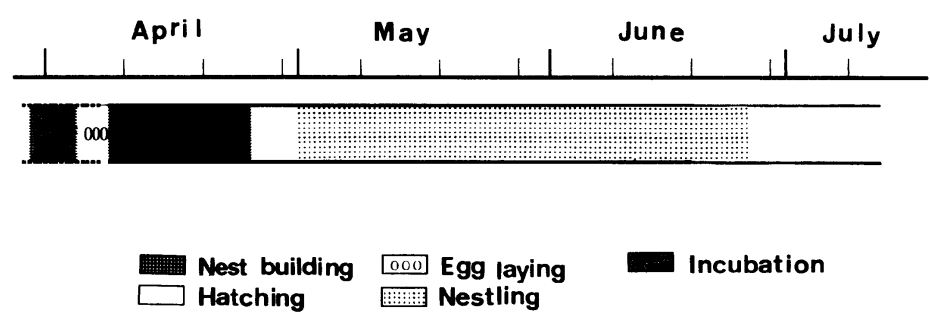

Fig. 2. Breeding stage of one pair of Coots on Lake Teganuma.

あのの，いまだ少数ながら繁殖個体群を抱えている(岡 1988)。オオバンの繁殖について日本で は詳細な研究がされていないことに加え, 污染湖手賀沼の繁殖個体群の繁殖状態を明らかにす ることの意義は大きく，ここにその結果を報告する。

\section{調查地と調查方法}

手賀沼は千葉県北西部に位置し，柏市，我孫子市，沼南町の 3 市町境界部に位置する。沼は 東西にのびる墂篦型をし，沼の中程の手賀大橋を境に，西側は上沼，東側は下沼と呼ばれてい る。本調查は下沼で行った (Fig. 1)。沼総面積は $6.5 \mathrm{~km}^{2}$, 周囲 $38 \mathrm{~km}$, 平均深度 $0.86 \mathrm{~m}$, 最大 深度 $3.8 \mathrm{~m}$, 水量 560 万 $\mathrm{m}^{3}$, 流水面積 $162 \mathrm{~km}^{2}$ であり, そのうち下沼は面積約 $2.2 \mathrm{~km}^{2}$, 周井約 
$9.6 \mathrm{~km}$ である（河川環境管理財団 1988）。

沼への 4 流入河川（大津川, 大堀川, 染井入落, 湖北集水路）からの生活雑排水なよ゙の流入 で, 沼の水質が污濁し, 沼の植生は, 全岸に沿い細い帯状につながるョシ Phragmites communis, マコモZizania latifolia, ヒメガマ Typha angustata の抽水植物群落と下沼南岸付近に局所的 に分布する中国産のハス（今回未調查群落区）を除いて, 浮葉・沈水両植物群落はほとんど無 い(千葉県水質保全研究所 1981, 浅間 1989)。

沼の魚もコイ Cyprinus carpio, キンブナ Carassius carassius, ハクレン Hypophthalmichthys molitrix, タイリクバラタナゴ Rhodeus ocellatus ocellatus, モッゴ Pseudorasbora parva, テナガェ ビ Macrobrachium nipponense などの污濁に抵抗力を持つ魚種に変わった（千葉県水質保全研究 所 1981, 浅間 1989)。沼の中に「すだて」という漁具や「張り網」の漁網が張り巡らされ, 釣 り人や観光客が 1 年を通じて訪れ，魚釣り船や遊覧船，ボートが出る観光沼となっている。

調查は 1990 年 4 月から 10 月の間に, 巣作り期 1 日, 抱卵期 4 日, 育㒛期 2 日の計 7 日間の 終日観察 (午前 5 時から午後 5 時まで) と, 計 63 日間の午前または午後の短時間の断片観察を 行った。翌 1991 年 3 月には分布の追跡調査を行った。1990年の観察はいずれも遊歩道の樹木 の陰や土手にブラインドをはり, その中から行った。巣の探索および巣材の識別, 卵数のカウ ント, 稱化の確認は, 胴長を使って沼に入り, 岸に沿って巣に近づき行った。卵の大きさ, 雊 の翼, 嘴峰, 跗蹠長の測定は, ノギスと物差しで行い, 卵と雛の体重の測定は銀科を使用した。 オオバンの雌雄は同色で判別が難しいため, 交尾の様子と額板の大きさ（雄の方が額板がより 大きい) から判断した。

観察結果は, (1) 営巣場所 (2) 繁殖初期（巣作り, 交尾) (3) 産卵期（第 1 卵産卵日から最

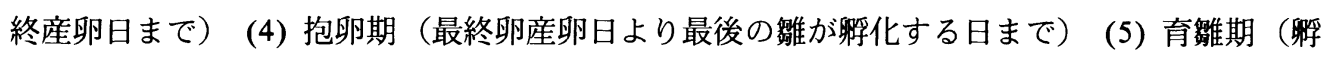
化, 最終卵孵化日より約 1 か月間）に分けてまとめた。

\section{結果および考察}

\section{1. 繁殖経過}

オオバンの繁殖経過を Fig. 2 に示した。最む早いものでは, 3 月下旬から 4 月初頭に造巣開 始が認められ，4月上旬に産卵，4月下旬から 5 月上旬に雊を孵化した。産卵は 7 月中旬まで見 られた。親鳥は雊の崢化後, 約 2 週間を越えると日中雛を連れて採餉行動をとっていた。粰化 後家族は約 8 週間近く一緒に行動するのが観察された。

海外のオオバンの繁殖開始時期をみると，イギリスでは 2 月終わりから 3 月中頃に営巣を始 め (Sage 1969), 中部ヨーロッパでは, 3 月初めから産卵を開始した (Glutz ら 1973)。当地の産 卵開始は 4 月の初めで約 1 カ月遅かった。さらにノルウェーやフィンランドでは 4 月末から産 卵を開始している。

1 回目の繁殖に失敗した 9 番 $(30 \%)$ は，すぐに営巣をやり直した。そのうち 4 番が 2 回ま で, 2 番が 3 回まで営巣のやり直しをした。ただし, それぞれの巣は, 同一の雌雄によるものか 断定できなかったが, 前の巣の近くに時期をずらして営巣していたので, その可能性は極めて 高かった。1 回目の産卵から再営巣の初卵日までの間隔は, 短いむので約 1 週間以内（3 日〜8 日), 長いものは10日〜20日間であった。しかし, 1 回だけの産卵で, 繁殖失敗後に再営巣を 


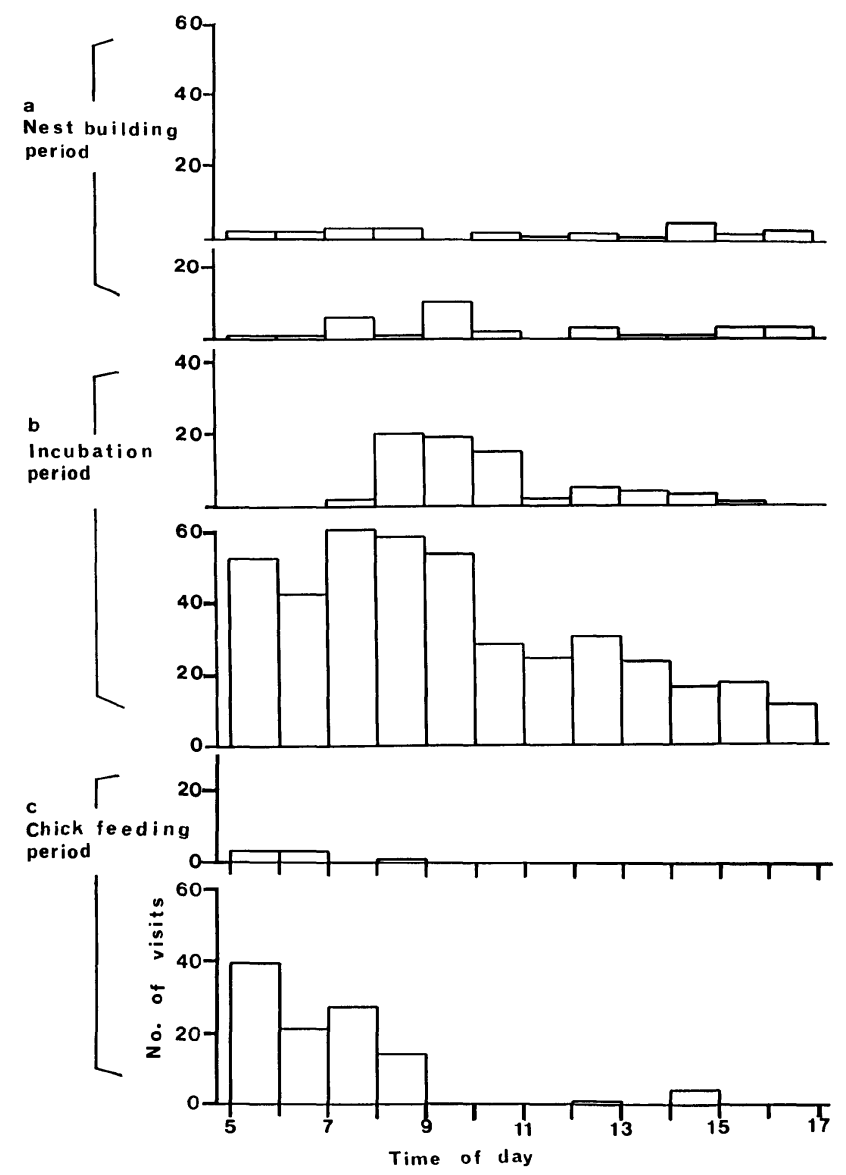

Fig. 3. The frequency of visits of a pair with nesting materials in relation to breeding season and time of day.

しない番あ計 7 巣 $(23.3 \%)$ あった。

9 月上旬には, 自分の繁殖なわばり内にとどまる個体と, 手賀大橋のたもとに群れになる個 体とが見られた。なわばり内で観察された個体は, 翌1991 年の 3 月初頭には, 合計 84 羽で あった。この出現場所は, 前年 1990 年の繁殖番のいた場所とほぼ同一場所であることから, 周 井の環境などに変化がないかぎり，年間を通して同一場所で生活する個体がいることが考えら れた。Cramp (1947) む, 前年度繁殖した番が, 番の相手を失うか争いに負ける以外は, 同一場 所に留まって繁殖することを報告している。群れになる個体では, 1990 年 9 月 7 日には成鳥 45 羽, 雊 5 羽が, 翌 1991 年 3 月初頭に成鳥 62 羽（幼鳥を含む）が, それぞれ手賀大橋横の船着 場でホテイアオイ Eichhornia crassipes などを採食しているのを観察した。

\section{2. 営䉾場所}

下沼では合計 30 番の営巣を確認した。営巣場所は Fig. 1 に示したように, 合計 32 力所に なった。オオバンの姿は観察されたものの巣の発見できなかった箇所は, 湖北集水路入口付近 
であった。30 番の総巣数は 43 巣であった。隣接する巣間距離は直線で $140 \pm 54.3 \mathrm{~m}$ (Mean士 $\mathrm{SD}, \mathrm{n}=11$ ，最小 $70 \mathrm{~m}$ 最大 $225 \mathrm{~m}$ ）であった。なお，うち 2 組の隣接巣は，両番のなわばり内 に別の番が入った様子が観察されなかったこと，両巣の巣と卵が何かの事情によって崩壊・消 失した後, 再営巣が観察されなかったことからみて, 同一番が 2 回繁殖したものと判断された。 営巣場所は, 合計 43 巣中 37 巣 $(86.0 \%)$ が, ヨシやマコモを背後に持つヒメガマ群落の中に あった。ヒメガマ群落中の巣の位置は, 広い水面に近いヒメガマが比較的低密度な場所にあっ た。これらの場所は湖水面側より見ると発見されやすいが， 5 月以降，植物の成長により湖岸か らは見つけられにくくなった。残り 6 巣 (14.0\%) はマコモ群落の中にあり，ヒメガマ群落の方 が営巣場所として好まれていることがわかった。

営巣数 43 巣の中で, 水面から産座まで一番高い巣は $21 \mathrm{~cm}$ であった。この一例を除き極端に 高いものは観察されなかった。これは，手賀沼が曙橋の水門で水量を調節していて，年間水面 の高さがほぼ一定しているためであろうと考えられる。

巣材は，ヒメガマの枯れた葉や茎が主で，他にヒメガマの生の葉やマコモ，ヨシの茎が少量 使われていた。このヒメガマは巣場所, 食物, 巣材などで利用されることから, 当地における オオバンの繁殖にとって, 大切な植物であることが考えられる。

\section{3. 造巣}

発見時に造巣中の巣のうち，巣材がわずかしか運ばれていなかったにもかかわらず，発見日 より 3 日目に第 1 卵が産卵された巣, 発見日より 6 日目，7日目に，それぞれ第 1 卵が産卵され た巣, 巣作りが 8 日間行われていたが巣が釣り人に壊された後, 数メートル沖に再営巣し, 3 日 目に産卵した巣があった。このことから, 第 1 卵産卵前の営巣日数は, 2 日から約 1 週間であ り, 巣によって数日の差がみられる。

巣材運搬回数の日周変化を Fig. 3 に示した。造巣期の巣材運搬は, 観察例が 1 例であるが, 早朝から夕刻まで 1 時間当たり数回の割合で連続的に行われていた (Fig. 3a)。運搬は雌雄両方 が行ったが, 巣を作るのは雌のみで, 雄は巣材を運んで雌に渡し, 巣上の雌が嘴で受け取り, 時々座り心地を確かめながら造巣した。産卵 4 日前の巣では, 雌雄で合計 26 回観察された。巣 材運搬は産卵期から育雊期にかけても，雌雄両方で絶えず行なわれていた (Fig. 3b, c)。第 1 卵 産卵当日の巣では, 午前 6 時 30 分 8 時 30 分の 2 時間に, 雌雄で合計 40 回行った。抱卵期の 巣材運搬回数は, 抱卵前期（最終卵産卵の翌日）の巣では, 雌雄で合計 32 回, 抱卵中期の巣で は合計 71 回, 抱卵後期の巣では合計 414 回（各午前 5 時から午後 5 時までの終日観察結果）行 われ，抱卵期における巣材運搬回数は，時期が進むにつれ増加の傾向を示した (Fig. 3b)。これ

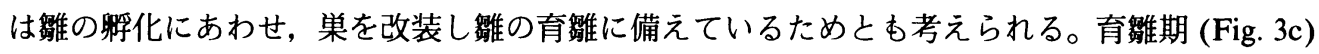
では, 抱雊第 1 日目の巣で 7 回観察された。このほかに育雊期には, これまでの巣と別の巣を

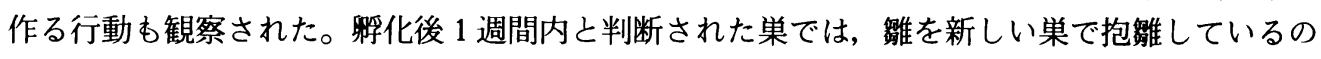
が観察された。その日の巣材運搬回数は, 合計 106 回, 造巣時間は計 38 分（持続時間最短 2 分 〜最多 11 分) であった。この時の巣材運搬は, 一方の親が雊の給䭒の世話をする間に, 他方の 親により行われた。

上述のように, 造巣期間が短期間で, しかも造巣が産卵之並行して行われ, 抱卵期も絶えず 巣材が補充され繁殖が進められることが, オオバンが 1 回目の繁殖に失敗しても, 何回か再営 巣できる条件となっていると考えられる。 


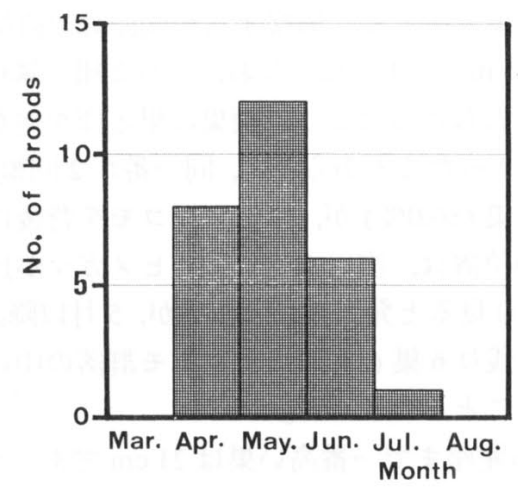

Fig. 4. Seasonal fluctuation in the date of first egg-laying of Coots on Lake Teganuma. $(n=27)$

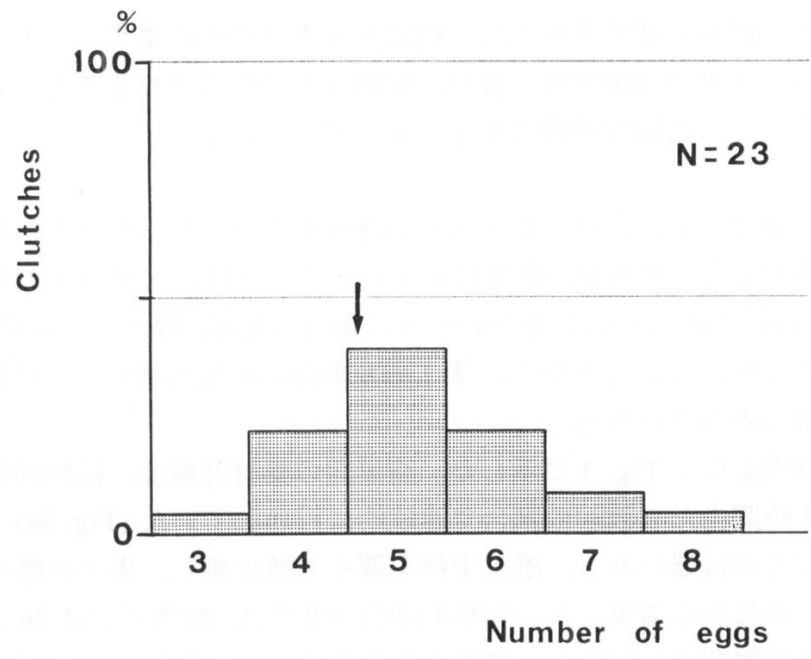

Fig. 5. Clutch size of Coots on Lake Teganuma. The arrow indicates mean clutch size.

造巣期間中の巣は，羽づくろいや交尾の場所としても使われていた。産卵 4 日前の巣では, 雌の入巣回数は計 11 回, 入巣時間は計 111 分であったが, その約 75\% (83 分) は羽づくろい, あとの約 25\% (28 分) が巣作りに使われていた。この時交尾は巣上で 4 回観察された。交尾方 法は, 泳いできた雄が素早く巣に登り, 宩の縁で頭を下げている雌の背に乗って行われた。終 了すると雄は速やかに水面に泳ぎ出ていった。

産卵用に使用する巣とは別に，近くに数本の葉や菱を集めたところを 1 箇所以上作って，そ こを侍にしていた番むいた。産卵用の巣の他に巣を作ることについては, アメリカオオバンが 造巣期に，ディスプレイイ用，産卵用，時用の 3 つの巣を作るという (Gullion 1954)。当地のオオ バンも，造巣期に同時に 3 箇所に巣を作り始めた番むあったが，この場合，産卵用の宩以外は どの巣にも巣材をほんのわずかのせただけであり，巣を侍用に使っていたこと以外，それぞれ の巣に決まった役割があるのかは，今回確認できなかった。 


\section{4. 産卵}

産卵は 1 日 1 卵の間隔で行われた。産卵時期は, 初卵日の確認された巣と産卵日の推定でき る計 27 巣でみると，5月がピークになり，その後 7 月にかけ減少していた (Fig. 4)。Kobayashi \& Ishizawa (1940) の報告では産卵期が 5〜7 月とある。同一番による産卵回数は, 再営巣屯含 めて 3 回まで観察された。ヨーロッパでは 1 繁殖期に 4 回の産卵む観察されている (Lelek 1958)。

一腹卵数は, $5.2 \pm 1.1$ 卵（ $\mathrm{M} \pm \mathrm{SD}, \mathrm{n}=23$, レンジ 3〜8 卵) であった (Fig. 5)。イギリスでは 5.9 卵 (レンジ 3〜9 卵) (Sage 1969), チェコスロバキアでは 7.1 卵 (レンジ 3〜13 卵) (Havlín 1970), ラトビアでは 7.6 卵 (Blum 1963), 西ドイッでは 7.9 卵 (Bezzel 1967) の報告があり, 日 本では小林 (1956) の 6卵〜12 卵がある。これらと比較して, 当地での一腹卵数は少ないほう だといえよう。この一腹卵数が少ない理由については, 緯度の違いのほか, 冬季の食物状況の 貣弱さも考えられる。産卵前の 3 月迄の食物摃取が十分か不十分かは，4月の産卵に影響を及 ぼすことから，この季節のオオバンの採餉量や採餌品目が問題になる。下沼と植生がほぼ同じ 印旛沼に於ける冬と春のオオバンの主な食物は，ヒメガマの茎である（原田 1988）ことから, 下沼のオオバンの主要餌種が産卵前の個体にとっては, 栄養が不足なことが考えられる。今後 冬季の索餌調查や体重の変動, 他地域との一腹卵数の検討をしてみる必要がある。

卵型は長径 $52.0 \pm 2.2 \times$ 短径 $35.5 \pm 0.8 \mathrm{~mm}(\mathrm{M} \pm \mathrm{SD}, \mathrm{n}=79$, レンジ $47.0 \times 32.0 \sim 57.0 \times 38.0$ $\mathrm{mm})$ であった。日本では Kobayashi \& Ishizawa (1932 1940) による $51.7 \times 33.7 \mathrm{~mm}(49.6 \times 32$ $\sim 57 \times 36.5, \mathrm{n}=16), \quad \exists$ ロッパの $53 \times 36 \mathrm{~mm}(44 \times 33 \sim 61 \times 40, \mathrm{n}=485)$ (Witherby 1947), イ ギリスの $52.57 \times 36.17 \mathrm{~mm}(44.2 \times 33.1 \sim 56.7 \times 39, \mathrm{n}=100)$ (David 1947) と近いあのであった。 卵重は, 産卵後 2 週間以内では約 $35 \pm 4 \mathrm{~g}(\mathrm{M} \pm \mathrm{SD}, \mathrm{n}=16$, レンジ $30 \sim 40 \mathrm{~g})$ であった。孵化 当日の卵重は $33.5 \mathrm{~g}(\mathrm{n}=2$, レンジ $33 \sim 34 \mathrm{~g})$ であった。

産卵時の入巣行動は, 第 1 卵産卵日の午前 6 時 30 分〜 8 時 30 分の 2 時間に, 入巣回数は 9 回, 入巣時間計 60 分を示す個体がいた。そのうち抱卵に使われたのは 8 回の 35 分のみであり,

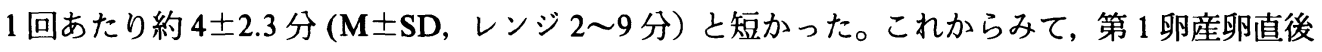
の成鳥は, まだ本格的な抱卵を開始しないことがわかる。巣を訪れる間隔は $8 \pm 4.7$ 分 $(\mathrm{M} \pm$ SD, レンジ 3〜16 分）と短く，頻繁に巣を訪れて来ることがわかる。

\section{5. 抱卵}

抱卵期の入巣時間の日周変化を Fig. 6 に示した。完全抱卵が産卵何日目から始まるかを，今 回の調查では確認することは出来なかったが, Lelek (1958) によると, 第 2 卵目から始まると いう。一方 Ruthke (1939) によると, 時々第 1 卵から抱卵する番ああるという。当地の観察で は, 第 1 卵産卵日の巣では, 前述したように抱卵が断続的かつ短時間であり, 第 2 卵目の巣で あ朝方卵に触れてみても, 卵は冷たく抱卵が継続して行われていると思われなかった。また, その時の卵は 1 2 本の草で被われていることがあり, 親が巣を開けていることが考えられた。 反対に第 3 卵目以後の巣では, 観察時に卵が冷たいというょうなことがなかったことから, 第 3 卵産卵後は完全抱卵に入っていることが考えられた。ある個体では，一腹の最終卵産卵の翌 日に，すでに完全抱卵に入っていたのを観察している。以後は何らかの妨害がないかぎり，抱 卵は雌雄交替で連続的に行われていた。本種は 1 シーズンに複数回繁殖する番むいるため繁殖 時期で抱卵開始時期が違う可能性む残されている。 
抱卵期の入巣時間は，入巣交代時之羽づくろいのわずかの時間を除いて，すべて抱卵に使わ れていた。そのため日中の抱卵時間は期間が進んでも増減することがなかった。雌雄別の日中 の抱卵時間を見ると, 最終産卵の翌日の巣では雌が計 515 分 (72.9\%), 雄は計 191 分 (27.1\%) であった。掱化 4 日前の巣では, 雌が 435 分 (60.9\%), 雄が 279 分 (39.1\%), 粰化 2 日前の巣 では, 雌が 405 分 (58.7\%), 雄が 285 分 (41.3\%) となり, いずれす雌の方が抱卵時間が多い傾 向にあった（各観察時間 720 分）。

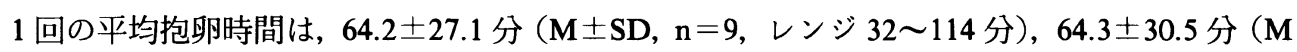
$\pm \mathrm{SD}, \mathrm{n}=8$, レンジ 28〜98 分), $44.6 \pm 31.9$ 分（ $\mathrm{M} \pm \mathrm{SD}, \mathrm{n}=13$, レンジ 5〜120 分）と, 番 ( $\mathrm{n}$ =3)によって違いがあったが, 平均約 1 時間近く連続して抱卵した。抱卵中雌雄は互に給餌し あうことはなかった。早朝は，2 時間以上採食せずに抱卵を続ける雌もいた。

抱卵期間は 21 日間と 25 日間の 2 例がみられた。von Blotzheim (1959) によると 23〜24 日, Lelek (1958) によると 22〜23 日である。

\section{6. 育雅}

(1) 㭌化

稱化は，全卵にほぼ一斉にひびが入るところから始まるが，㮲が卵款より出てくる日はずれ ていた。これはサギ類であ見られる非同時孵化（井上 1980）と同じであった。粰化は必ずしも 1 日 1 卵之規則正しくはなく，同日に 2 卵以上が粰化することがあった。6月 12 日〜 13 日の 2 日間で 4 卵捊化した巣と 5 卵のうち 6 月 29 日に 1 卵，6月30日〜7月 1 日の 2 日間に 3 卵， 7

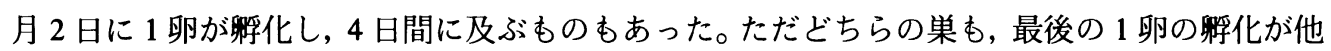
の卵より遅くなる傾向があった。

雊は巣立ち後わずかな時間で離巣し, 巣の中にまだ卵款が残っている状態でも, 人間が近づ くと泳ぎ出た。孵化当日雛の大きさは, 平均体重 $23 \mathrm{~g}$, 翼長 $17 \mathrm{~mm}$, 嘴峰長 $16 \mathrm{~mm}$, 跗蹠長 20 $\mathrm{mm}$, 尾長 $0 \mathrm{~mm}$ (各 $\mathrm{n}=3$ ) であった。これらは, 手賀沼で魚網に入って死んで採集された成鳥 の翼長 $200 \mathrm{~mm}$, 嘴峰長 $49.8 \mathrm{~mm}$, 跗蹠長 $58.7 \mathrm{~mm}$, 尾長 $57.4 \mathrm{~mm}$ (各 $\mathrm{n}=6$ ) と比較して, 翼長 は成鳥の $8.5 \%$, 嘴峰長は $32.1 \%$, 跗蹠長は $34.1 \%$ であり, 跗蹠が 1 番成長した状態で餒化し ていることがわかった。

\section{(2) 抱雅}

育雊 1〜2 日目の巣では, 抱卵期の巣をそのまま使って雛を抱雊していたが, 数日後近くに育 雊用の別の巣を作って雛を抱雊した番が 3 例観察された。育雊用の巣はそれぞれ抱卵期までの 巣から $7 \mathrm{~m}, 8 \mathrm{~m}, 9.7 \mathrm{~m}$ の近距離に作られた。いずれす中央部が平らになり, 抱卵期の巣より中 央が盛り上がったように見えた。育雊用の巣は約 2 週間使われていた。

抱雊は雌雄で行っていたが, 交代は抱卵期のように連続的に規則正しくしなかった。孵化直 後の抱雊時間は, 計 458 分（レンジ 30〜141 分）であり, 午前 5 時から午後 5 時まで観察時間 の $63.6 \%$ にあたった。しかし別の育雊用の巣で粰化後 1 週間ぐらいの雊を抱いていた親鳥で は, 計 50 分 (レンジ 3〜19 分, 日中総観察時間中の 7\%) にすぎなかった (Fig.6)。これは捊化 直後の抱雊時間の $11 \%$ に減っており, 育雊時期が進むにしたがって, 抱雊時間も減少すること を示していた。また，1回の抱雊時間む育雅が進むにつれ短くなっていた。

\section{(3) 給饵}

育雊中, 巣の中で雛への給餌は観察されなかった。給餉方法は, いずれも雊が巣の横の水面 


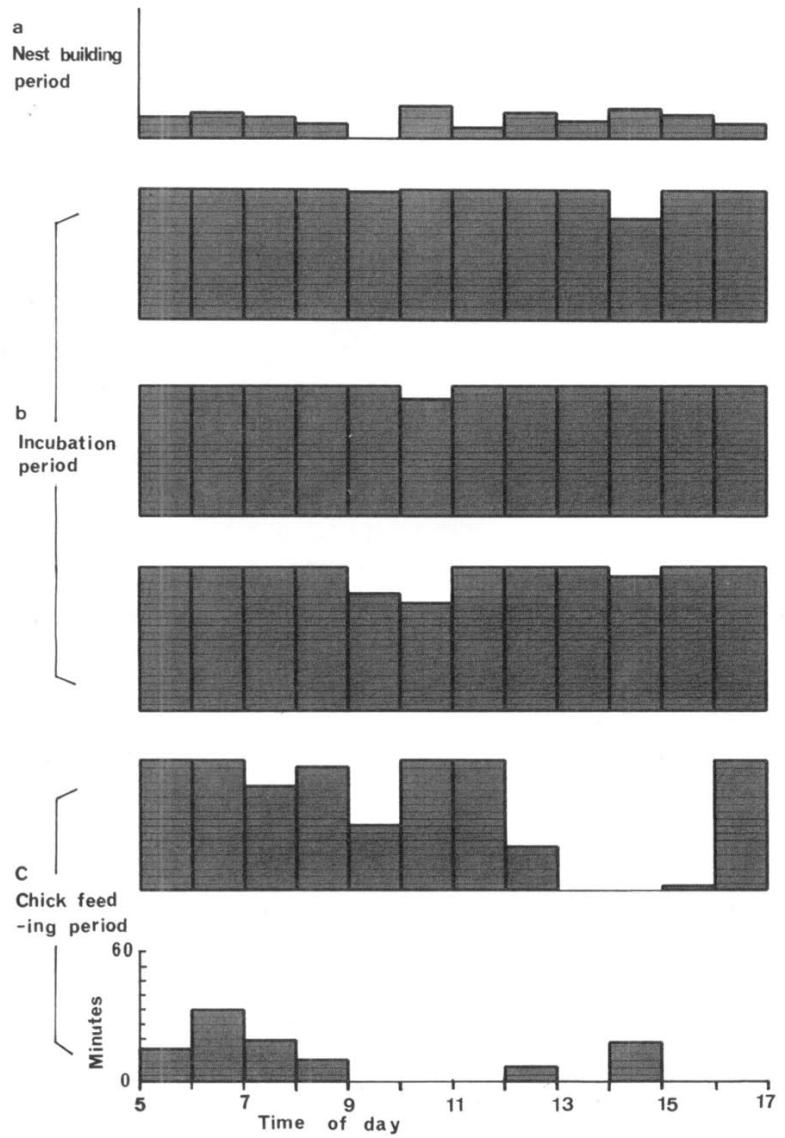

Fig. 6. Diural change in nest-attending time during incubation and nestling periods.

上に出て, そこに親が餉を持ってきて行うことが多かった。巣近くでの給餌は, 最終卵梛化後 1〜2 日目では 1 日計 3 回観察された例があったが, 渐化後 2 週間では 1 日 26 回観察される例 があった。雛の餉はヒメガマの根に近い䯣（1例)，モッゴ（2 例)，テナガエビ（1例）が観察 された。

\section{7. 繁殖成功率}

産卵と孵化の確認できた計 28 巣で，総産卵数は 126 卵になった。その内卯化した数は 40 卵

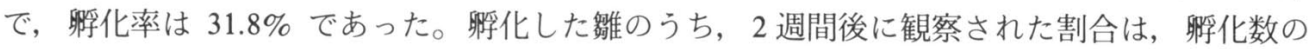
$37.5 \%$, 総産卵数の $11.9 \%$ になり, 梛化時の約 $1 / 3$ に減っていた。さらに 1 加後になると, 孵化数の $27.5 \%$, 総産卵数の $8.7 \%$ に減り, 孵化時の $1 / 4$ になった。番が 19 ペア確認されてい るので, 1 汃後の 1 番当たりの雛数は, 約 0.6 羽になり, 当地におけるオオバンの繁殖成功率 は極めて低いことがわかった。

育雊用の巣を除いた総営巣数 43 巣での繁殖成功率をみる之, 巣作り途中で巣の崩壊したも の 5 巣 $(11.6 \%)$, 産卵途中で放棄又は巣の崩壊したもの 2 巣 $(4.7 \%)$, 産卵後抱卵期に巣が崩 壊, 卵屯消失した巣 10 单 $(23.3 \%)$, 同じく産卵後卵のみ消失した巣 8 巣 $(18.6 \%)$, 躬化成功 11 

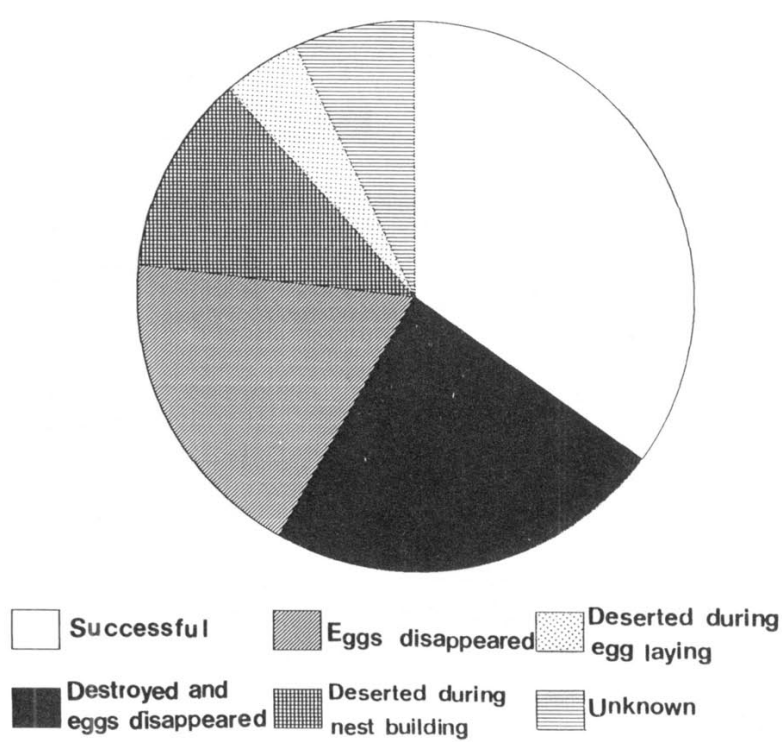

Fig. 7. Success and failure chicks among 43 Coot nests on Lake Teganuma.

巣 $(25.5 \%)$, 不明 3 巣 (7.0\%) であった (Fig. 7)。巣の崩壊の理由には, イ夕チや野犬や漁船に よるもの，卵のみがなくなった理由はカラスによる例があった。巣の放棄は人間（調查者や釣 り人) の影響によるものがあった。この結果, 繁殖不成功巣は観察巣全体の $76 \%$ と大きな割合 であった。

外国での捊化率は, ドイツの Ismaning の沼沢 65\% (Bezzel 1959), ラトビアの Engure 湖の 1960 年, 1962 年にそれぞれ 75\%,77\% (Blum 1963), チェコスロバキアの Náměšt の沼沢 $80 \%$ (Havlín 1970), モラバ丘陵 43\% (Lelek 1958), イギリスの Somerset 35\% (Alley \& Boyd 1947), Hertfordshire 34\% (Sage 1969) がある。これらと比較して, 当地の繁殖成功巣率 32\% は低い方 にある。この原因については, 営巣数の $76 \%$ が, 孵化以前の段階で失敗していることが大きな 理由であり, 繁殖不成功の要因として考えられる捕食者及び人間の影響, またそれに伴う卵放 棄が大きな影響を及ぼしていると考えられる。そしてこの繁殖率の低さは, 当地の個体群の増 加を抑える要因ともなっていると考えられ, 今後不成功の要因について詳細な調查が必要であ り, 保護の対策が求められる。

この研究は, 1990 年度長野県教職員内地留学制度により, 山階鳥類研究所に内留したときの あのである。研究をはじめご指導頂いた研究所所長・黒田長久博士に心より感謝申し上げる。 また，ドイッ語論文の翻訳をしていただいた三浦武亜氏，オオバンの食物と採饂行動のデー夕 を閲覧させて頂いた原田俊司氏, 資料や検測方法等でご協力頂いた研究所の所員の方々や内留 期間中公私共に励まして頂いた元鍋屋田小学校校長松橋英幸氏，論文に貴重なご指摘を頂いた 岡 奈理子博士他本誌レフリーの方々に，心より感謝申し上げる。 
摘 要

1. オオバンの繁殖生態を千葉県我孫子市手賀沼において 1990 年 4 月から 10 月まで調查し た。

2. 営巣は, 雄が巣材を運び, 雌がそれを嘴で受けて行った。営巣日数は約 2〜7 日であり, この時の巣は交尾や羽の繥いにも使われていた。営巣場所は発見巣 43 巣中 37 巣がヒメガマ群 落中にあり，6巣はマコモ群落にあった。巣材はヒメガマがほとんどであった。巣材の補給を抱 卵期, 育雊期も続けた。抱卵期には雛の孵化にあわせるように巣材運搬回数が増加していき, 孵化時に巣は育雅用として数日使われた。

3. 産卵は 4 月上旬に始まり，5月にピークをむかえ， 7 月に終わった。産卵は 1 日 1 卵で， 一腹卵数は平均 5.2 卵, 卵重は平均 $35 \mathrm{~g}$, 大きさは平均 $52.0 \times 35.5 \mathrm{~mm}$ であった。

4. 抱卵は雌雄で行い, 特別な事情のないかぎり終日連続して, 途切れることなく捊化まで 続いた。1 回の抱卵時間は平均 51 分, 抱卵日数は 21 日〜25 日であった。また抱卵中は雌雄相 互の給餌は見られなかった。煼の粰化後数日すると, それまでの巣と別に育雊用の巣を作って 雅を育てた。雊への給餉は水面上で行われた。

5. 28 巣で 126 卵が産卵され，その $32 \%, 40$ 羽が梛化した。しかし 2 週間後に観察される雊 数は $12 \%$ に減少していた。営巣数 43 巣中, 稱化に成功した巣は 11 巣, $26 \%$ であった。卵の 消失や巣の崩壊はイ夕チやカラス，人間，漁船の影響によるものが観察された。

6. 当地のオオバンの個体数の減少原因は, 繁殖成功率の低さにあるとみることが出来る。 今後繁殖成功率を低めている原因を詳細に研究する必要がある。

\section{引用 文 献}

浅間茂 1989. 手賀沼の生態学. 崙書房.

Alley, R. \& Boyd, H. 1947. The hatching and fledging succes of some Coot. Brit. Birds 40: 199-203.

Alley, R. \& Boyd, H. 1948. The function of the head-coloration of the nestling Coot and other nestling Rallidae. Ibis 90: 582-593.

Alley, R. \& Boyd, H. 1950. Parent-young recognition in the Coot Fulica atra. Ibis 92: 46-51.

Bezzel, E. 1959. Beobachtungen zur Nistökologie des Bläßhuhns. Vogelring 28: 81-90.*

Blum, P. N. 1963. BläBhuhn in Lettland. Ornitologija 6: 272-279.*

Brazil, M. A. 1991. The birds of Japan. Christopher Helm Ltd. p. 115.

千葉県水質保全研究所 1981. 手賀沼の污濁と生態系.

Cramp, S. 1947. Note on territory in the Coot. Brit. Birds 40: 194-198.

Cramp, S. et al. (Eds.) 1980. Handbook of the birds of Europe, the Middle East and North Africa. Vol. II, pp. 599-610. Oxford University Press.

David, A. B. 1947. The birds of the British Isles. XII, pp. 243-253. Oliver \& Boyd.

Gordon, W. 1954. The reproductive cycle of American Coot. Auk 71: 366-412.

Gullion, G. W. 1951. The frontal shield of the American Coot. Wilson Bull. 63: 157-166.

Gullion, G. W. 1953. Territorial behavior of the American Coot. Condor 55: 169-186.

Gullion, G. W. 1954. The reproductive cycle of American Coots in California. Auk 71: 366-412

原田俊司 1988. 印㢖沼におけるオオバンの食物と採餉行動. 1988 年度日本鳥学会大会要旨集, p. 6.

Havlin, J. 1970. Breeding season and success in the Coot on the Náměštské rybniiky ponds (Czechoslovakia). Zool. listy 19: $35-53 .^{*}$ 
Hendrickson, G. O. 1936. Observation on nests and young of the Coot. Wilson Bull. 48: 216-218.

井上良和 1980. コサギにおける非同時性邪化 Asynchronous hatching にいたる過程。鳥 12(2): 71-79.

伊豆沼湖沼群の自然を守る会 1985. 伊豆沼の鳥たち.

河川環境管理財団編 1988. 日本の湖沼. 河川環境管理財団

清棲幸保 1965. 日本鳥類大図鑑 II: 707-708. 講談社

Kobayashi, K. \& Ishizawa, J. 1932 1940. The eggs of Japanese bird, Part 4, p. 52. Kobe.

小林桂助 1956. 原色日本鳥類図鑑 保育社 $212 \sim 213$.

黒田長久 1985. 水鳥の里, 手賀沼一我孫子市移転に当たって一山階鳥研報 17: 3-8.

黒田長久・森岡弘之 1989. 世界の動物 分類と飼育 10-II [ツル目] 東京動物園協会.

Lelek, A. 1958. Contribution to the bionomy of the Coot. Zool. listy 7: 143-168.*

岡 奈理子 1988. 沼及び流域の開発が手賀沼の水禽に与えた影響. 手賀沼 1990 年代の課題一鳥と人の共存 -, pp. 71-89. 山階鳥類研究所.

Ripley, D. 1977. Rails of the world. pp. 321-326. M. F. Feheley.

Ruthke, P. 1939. Beobachtungen am Bläßhuhn. Orn. Mber. 47: 141-147.*

Sage, B. L. 1969. Breeding biology of the Coot. Brit. Birds 62: 134-143.

斉藤源三郎 1931. 千葉県共同狩猟地の概況 (二), 三 手賀沼共同狩猟地. 鳥 7: 87-89

Sooter, C. A. 1942. Ecology and management of the American Coot Fulica americana americana Gmelin. Iowa State Col. J. Sci. 17: 126-128.

杉森文夫・松原健司・岩淵 聖 1989. 手賀沼に飛来する力モ類の環境利用之水質污濁の関係. 山階鳥研報 21: $234-244$.

Takatsukasa, N. 1967. The birds of Nippon. pp. 382-393. Maruzen Co.

Von Blotzheim, U.N.G. 1959. Geschlechtsmerkmale, Gewicht und Alterskennzeichen beim Bläßhuhn. Orn. Beob. 56: 110-125*

Von Blotzheim, U.N.G. 1973. Handbuch der Vögel Mitteleuropas, Band 5, pp. 519-566. Akademische Verlagsgesellschaft, Wiesbaden.

Witherby, H. F. 1947. The handbook of British birds. Vol. 5, pp. 204-208. H. F. \& G. Witherby. Lond.

山崎博道 1976. バンの禽舎内繁殖. 鳥 25: 65-68.

*: 著者未読, Von Blotzheim, U.N.G. Ed. 1973 から引用

北島信秋：長野県長野市立鍋屋田小学校

現在 長野市立若梘小学校 $\mathbf{0} 381$ 長野市東条 810 